\title{
Influence of Aging, Oxygen, and Moisture on Ethanol Production from Cabbage Seeds
}

\author{
Corinne F.J. Rutzke ${ }^{1}$ \\ Department of Biological and Environmental Engineering, 120 Riley Robb Hall. Cornell University, \\ Ithaca, NY 14853 \\ Alan G. Taylor \\ Department of Horticultural Sciences, Sturtevant Hall, Cornell University, Geneva Agricultural \\ Experiment Station, Geneva, NY 14456 \\ Ralph L. Obendorf \\ Department of Crop and Soil Sciences, 617 Bradfield Hall, Cornell University, Ithaca, NY 14853
}

\begin{abstract}
Additional Index words. Brassica oleracea, ADH, seed quality, ANA ratio index
Abstract. A seed quality test developed by Kataki and Taylor (1997) measures the anaerobic-to-aerobic (ANA) ratio of ethanol production and the relationship of the ANA ratio index-to-seed quality has been tested in several species. To expand the usefulness of the ANA ratio index and to optimize the test conditions, a series of studies was performed using cabbage (Brassica oleracea $\mathbf{L}$. var. capitata $\mathbf{L}$.) seeds as a model. It was hypothesized that ethanol production in cabbage seeds would be influenced by aging treatment, hydration level, seed integrity (grinding), and oxygen availability. Cabbage seeds were subjected to controlled aging treatments $\left(40{ }^{\circ} \mathrm{C}\right.$ at $70 \%$ relative humidity for $0,7,14$, 21 , and $28 \mathrm{~d})$. Seed samples were incubated with a glucose $(50 \mathrm{~mm})$ potassium phosphate buffer $(5 \mathrm{~mm}, \mathrm{pH} 5.6)$ at $25^{\circ} \mathrm{C}$ for $24 \mathrm{~h}$ (shorter than the time required for germination). The water concentration levels tested in the current study were $0.18,0.22,0.54,0.80,1.22,1.86,3.00,5.67$, and $10.0 \mathrm{~g}$ of $\mathrm{H}_{2} \mathrm{O}$ per gram of dry seeds. Ethanol production was measured in the supernatant of seed extracts using immobilized enzyme technology. The experiments were performed in ambient oxygen conditions and under nitrogen. Ethanol production was greater in aged than nonaged intact seeds at all water concentrations tested. Nonaged seeds under nitrogen had reduced ethanol production at $\leq 0.54 \mathrm{~g}$ of water per gram of seeds, indicating that low seed water concentration limited ethanol production. Nonaged seeds in ambient oxygen at $\geq 1.22 \mathrm{~g}$ of water per gram of seeds had elevated ethanol production, indicating that a hypoxic environment was created by excess seed water. Thus, a water concentration between these values is recommended for the ANA ratio index test for cabbage seeds. The opposite trend of lower ethanol production in aged than nonaged seeds was measured if seeds were ground before the hydration. Seed integrity experiments suggest that lower ethanol production observed in aged ground seeds may be attributed to hypoxia resulting from rapid hydration damage that results with loss of seed-coat integrity.
\end{abstract}

The rate of metabolism and respiration in dry seeds is very low. Before germination, seeds become metabolically active upon imbibition of water, and respiration rate increases. Under aerobic conditions, water and $\mathrm{CO}_{2}$ are products of mitochondrial respiration and oxidative phosphorylation. Under anaerobic or hypoxic conditions (in the absence of oxygen or under conditions of low oxygen, respectively) ethanol is produced from pyruvate in the ethanol fermentation pathway of metabolism (Garrett and Grisham, 1995).

The anaerobic-to-aerobic (ANA) ratio index, a seed quality test, uses the ratio of anaerobic (AN) and aerobic (A) ethanol production in seeds and was developed as a rapid, sensitive,

\footnotetext{
Received for publication 5 Oct. 2006. Accepted for publication 1 Oct. 2007. We thank Cathy Roe, Grace Feng, and David Paine for their very helpful laboratory assistance and Terry Acree for kindly allowing access to his laboratory and use of the nitrogen glove box equipment. We also thank Harris Moran Seeds (Modesto, CA) for kindly donating seeds for this work. We thank the National Space and Aeronautics Administration for supporting this work through the Graduate Student Researcher's Program at Kennedy Space Center, Program Grant No. NGT10-52607.

The use of a brand name, trademark, or proprietary product does not imply endorsement or constitute a guarantee or warranty of the product by Cornell University or NASA and does not imply its approval to the exclusion of others that also may be suitable.

${ }^{1}$ Corresponding author. E-mail: CFJ4@cornell.edu.
}

predictive indicator of seed quality (Kataki and Taylor, 1997, 2001; Taylor et al., 1999). The ANA ratio index test was shown to detect the early phases of seed aging for several species. The test for cabbage seeds uses two states of oxygen availability (aerobic and hypoxic) and two conditions of seed integrity (intact seeds and ground seeds) from seeds of the same lot (Taylor et al., 1999). The ANA ratio index was previously described and used, but the mechanisms and roles of limiting substrates behind this useful test are not understood.

The current work was conducted to optimize ANA ratio test protocol by determining optimal water concentration for test samples. In addition, characterization of ethanol production at different levels of seed quality, seed integrity, seed water concentration, and oxygen availability will provide insights into the underlying mechanisms. An excess of water, a depletion of oxygen, inhibition or degradation of the tricarboxylic acid cycle enzymes or oxidative phosphorylation enzymes could individually or collectively redirect carbon metabolism from complete respiration to ethanol production.

\section{Materials and Methods}

Controlled AGING OF SEeds. Seeds of cabbage 'Blue Gem' $F_{1}$ (lot \#128836; Harris Moran Seed Co., Modesto, CA) were 
moisture equilibrated to a water activity $\left(A_{w}\right)$ of $0.7 A_{w}$ in a glycerol/water vapor phase equilibration chamber (Forney and Brandl, 1992; Taylor et al., 1999). Water activity was measured using a water activity meter (dew point meter DP989M; Protimeter plc, Marlow, UK). Oven dry moisture concentrations were determined to verify water activity readings (Taylor et al., 1997). Moisture-equilibrated seeds were aged by placing them in sealed plastic bags and in water-proof aluminum packets. The sealed packets were incubated at $40{ }^{\circ} \mathrm{C}$ (Komba et al., 2006) in a water bath for 0 (control), 7, 14, 21, or $28 \mathrm{~d}$.

Germination. Germination tests were performed according to Association of Official Seed Analysts rules for cabbage seeds (AOSA, 1993, 1992). Two hundred seeds (four replicates of 50 seeds per replication) were tested for each aging treatment using moist germination paper towels. Seed samples were further characterized with a duplicate set of 200 seeds to determine time-to-visible germination (i.e., radical emergence). After germination, the number of normal and abnormal (deformed) seedlings was recorded. Germination counts were made $24,48,72,96$, and $120 \mathrm{~h}$ after the initiation of imbibition.

SAMPLE PREPARATION FOR ETHANOL PRODUCTION INFLUENCED BY WATER AVAILABILITY. Intact and ground seeds were tested. For tests on intact seeds, samples were removed directly from plastic bags and weighed. For tests on ground seeds, cabbage seeds were ground by three short (1-2 s) pulses in a coffee mill and sieved through a no. 14 screen (1.4-mm square openings). Pieces retained by a no. 20 screen (0.9-mm square openings), below the no. 14 screen, were the desired particle size and were then cleaned of most seedcoat material. A 0.3-g sample of seeds to be processed (intact or ground) was placed in a $50-\mathrm{mL}$ conical centrifuge tube. Test tubes that were smaller than $10 \mathrm{~mL}$ were found to indirectly influence ethanol production (data not shown; Johnson, 1998), as oxygen availability was limiting to respiration. The use of a $50-\mathrm{mL}$ test tube eliminated this artifact. Seed sample weights were recorded to the nearest $1 \mathrm{mg}$. A $50 \mathrm{~mm}$ glucose $/ 5 \mathrm{~mm}$ potassium phosphate buffer ( $\mathrm{pH} 5.6$ ) was added to each sample. The mildly acidic buffer solution served to drive the reaction toward ethanol production catalyzed by the alcohol dehydrogenase (ADH) enzyme in seeds (rather than lactate production) and provided an exogenous carbon source for the reaction (Taylor et al., 1997). The amount of buffer added to each seed sample was adjusted for the seed sample's initial moisture concentration, the desired final moisture concentration, and the weight of the sample. Eq. 1 was used to determine the amount (milliliters) of water to add to a sample of specified weight (grams), the initial moisture concentration $\left(\mathrm{MC}_{\mathrm{i}}\right)$ and the desired final moisture concentration $\left(\mathrm{MC}_{\mathrm{f}}\right)$ :

$\mathrm{X}$ milliliters water $=($ grams seed $) \times\left(\mathrm{MC}_{\mathrm{f}}-\mathrm{MC}_{\mathrm{i}} / 1+\mathrm{MC}_{\mathrm{i}}\right)[1]$

The water concentration levels tested in the current study were $0.18,0.22,0.54,0.80,1.22,1.86,3.00,5.67$, and $10.0 \mathrm{~g}$ of $\mathrm{H}_{2} \mathrm{O}$ per gram of dry seeds. After addition of the buffer, samples were incubated for $24 \mathrm{~h}$ at $25{ }^{\circ} \mathrm{C}$. After incubation, samples were chilled on ice and homogenized for 30 to $45 \mathrm{~s}$ (Ultra Turrax \#18/10S1; Janke \& Kunkel, Cincinnati) with sufficient water to bring the final water:seed ratio to 10:1 (by weight). Homogenized samples were centrifuged (5000 $g_{a}$ ) for $5 \mathrm{~min}$. Supernatant was decanted into a $2-\mathrm{mL}$ vial and placed in an automatic sampler for ethanol concentration analysis. Ethanol concentration was measured by a YSI analyzer (model 2700;
Yellow Springs Instruments, Yellow Springs, OH) that uses membrane-immobilized ethanol oxidase enzyme (EC 1.1.3.13) for quantification of ethanol (Taylor et al., 1999). Each study was performed twice. The YSI analyzer also responds to methanol. Methanol has been detected in seeds and plant tissue and is formed by pectinmethylesterase (E.C. 3.1.1.11; Frenkel et al., 1998; Koch et al., 1999; Markovic and Obendorf, 1998, Obendorf et al., 1990). However, our system was tested previously to verify that methanol was not detected in the seed samples reported herein (Taylor et al., 1999).

Alternate methods of evaluating Seed Quality. For comparison, two other methods of seed quality evaluation were considered: the coefficient of rate of germination (CRG) method (Bewley and Black, 1994) and the standard percent germination method. The CRG method uses Eq. 2 to determine the $C R G$ value on $t$ days after initiation of imbibition.

$$
\mathrm{CRG} \text { value }=\left\{\left[\sum \mathrm{n} /\left(\sum \times \mathrm{n}\right)\right] \times 100\right\}
$$

where $\mathrm{n}=$ number of seeds germinating on day $\mathrm{t}$.

Percentage germination on $t$ days after initiation of imbibition was determined using Eq. 3.

$$
\text { Percentage germination }=\left[\left(\sum \mathrm{n} / \mathrm{N}\right) \times 100\right]
$$

where $\mathrm{n}=$ number of seeds germinating on day $\mathrm{t}$, and $\mathrm{N}=$ the total number of seeds imbibed (germinated + nongerminated seed).

SAMPLE PREPARATION FOR ETHANOL PRODUCTION INFLUENCED BY OXYGEN AVAILABILITY. A wide range of water availability was examined, and selected treatments provided sufficient water (i.e., all treatments with $>0.8 \mathrm{~g}$ of $\mathrm{H}_{2} \mathrm{O}$ per gram of seeds) to create a hypoxic environment. These treatments created a change in two factors: water availability and oxygen availability. To test the influence of oxygen availability alone, samples were prepared as described above, but all procedures through incubation were performed inside a nitrogen glove box (G1000; Allied Engineering and Products Corp., Alameda, CA). Seed samples were purged with HQ-grade nitrogen gas for $18 \mathrm{~h}$ before the addition of nitrogen-purged buffer solution. Glove box humidity was maintained at $70 \%$ relative humidity. Oxygen meter (GC501; GC Industries, Fremont, CA) readings were taken throughout the process. Oxygen levels were maintained at $<1 \%$ by adjusting the nitrogen flow rate into the glove box. Temperature during the nitrogen glove box incubation was 21 to $25^{\circ} \mathrm{C}$. After incubation in the glove box, the seed samples in $50-\mathrm{mL}$ tubes were capped and removed from the glove box for final processing. Sample homogenization, centrifugation, and ethanol sampling occurred at ambient oxygen levels (measured $20 \%$ to $21 \% \mathrm{O}_{2}$ ). Nitrogen-purged distilled water was used for bringing all samples to final water concentration of $10 \mathrm{~mL}$ of water per gram of seeds $(\approx 3 \mathrm{~mL}$ per test tube). The nitrogen glove-box study was performed twice.

SEed INTEGRITY EXPERIMENTS. To test the hypothesis that changes in ethanol production upon grinding seeds may be from changes in seed integrity, aged seeds were treated four ways, each representing a progressive increase in damage to seedcoat integrity: 1) intact whole seeds (control), 2) pinhole punctured, 3) ground, and 4) crushed seed. Inserting a needle once into each seed created the pinhole-damaged seed, and the seedcoat remained on the seed. Crushed seeds were prepared by crushing whole intact seeds with a flat-edge knife against a flat surface. 
Crushed seeds included seedcoats. The intact and ground treatments were as described above. Two moisture concentrations were tested for each seed-integrity condition: one aerobic $(0.3 \mathrm{~g}$ of water per gram of seeds) and one hypoxic ( $10.0 \mathrm{~g}$ of water per gram of seeds) under ambient oxygen conditions. Three samples of each were tested. All other protocols were as described above for determination of ethanol production. The experiment was performed twice.

Tetrazolium TEST OF DEHYDROGENASE ACTIVITY IN GROUND SEED. To test the hypothesis that changes in ethanol production upon grinding seeds may be from changes in ADH (E.C. 1.1.1.1) enzyme activity as a result of rapid hydration damage-induced changes in membrane integrity, a tetrazolium staining test was performed. Tetrazolium staining is a dehydrogenase test and will only provide an indication of dehydrogenase activity (i.e., not ADH activity specific.) Intact seeds did not absorb the stain uniformly through the seedcoat compared with ground seeds and thus were eliminated from the test. A $0.25 \%$ tetrazolium solution in $10 \mathrm{~mm}$ potassium phosphate buffer ( $\mathrm{pH} 7)$ was added $(10 \mathrm{~mL}$ of stain solution per gram of seeds) to four seed conditions: ground and pinhole-damaged control seeds and ground and pinhole-damaged aged seeds (28 d at $40{ }^{\circ} \mathrm{C}$ and $70 \%$ relative humidity). After $24 \mathrm{~h}$ at $25^{\circ} \mathrm{C}$ in this hypoxic condition, excess liquid was decanted. Seed samples were dried and a $0.25 \mathrm{~g}$ sample was transferred to a $50-\mathrm{mL}$ centrifuge tube. Acetone $(5 \mathrm{~mL})$ was added and the sample was homogenized and then centrifuged (5000 $g_{a}$ ) for $10 \mathrm{~min}$. There were three replicates per treatment (one test tube sample represents one replicate). Absorbance at $475 \mathrm{~nm}$ was determined using a spectrophotometer (model DU-64; Beckman Instruments, Fullerton, CA).

Statistical Treatment of Results. Data from the experiments was combined and averaged. Standard deviation and standard error were calculated using Excel software (Microsoft Corp., Redmond, WA). Comparisons of the means of treatments were determined using Student's $t$ test using Minitab (V12; Minitab, State College, PA).

\section{Results and Discussion}

Aging of Seed: Germination and germination rate TESTING. Percent total germination for controls and seeds aged for $7 \mathrm{~d}$ were similar, but decreased with aging $>21 \mathrm{~d}$. However, all aging treatments demonstrated a delay in time to visible germination after initiation of imbibition (Fig. 1A). The number of normal seeds decreased with increasing aging treatment, whereas the number of abnormal seeds increased (Fig. 1B).

ANA INDEX TEST FROM CONTROL AND AGED SEEDS. Hypoxic and aerobic ethanol production from intact and ground seeds aged for 0 to $28 \mathrm{~d}$ were analyzed and then ANA ratios were calculated and compared with germination changes. The ANA ratio test had greater sensitivity to early changes in quality of the aged seeds (aged 7-14 d) than the percentage germination test and the coefficient of rate of germination (CGR) index based on time and percentage germination (Table 1). The ANA ratio test predicted seed quality in $24 \mathrm{~h}$, whereas $120 \mathrm{~h}(5 \mathrm{~d})$ was required for the percentage germination and $\mathrm{CRG}$ index tests on cabbage.

INFLUENCE OF MOISTURE CONCENTRATION ON ETHANOL PRODUCTION. In control intact seeds, ethanol production was limited when seed water concentration was less than $1.86 \mathrm{~g}$ of water per $\mathrm{g}$ of seeds (Fig. 2A). A water concentration of $0.8 \mathrm{~g}$ of
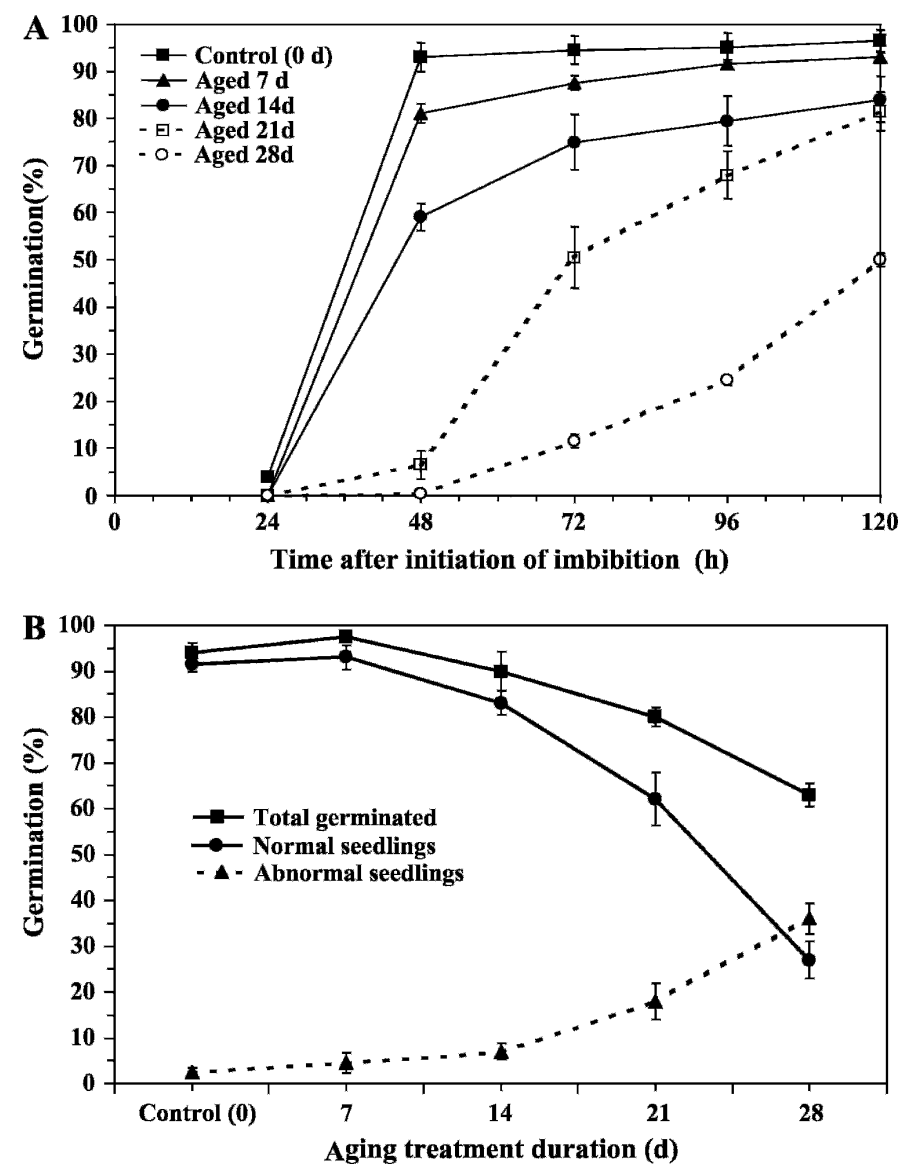

Fig. 1. Seed aging treatments decreased percentage of germination and time to visible germination, and increased the number of abnormal seedlings. (A) Mean percentage germination $( \pm \mathrm{SE})$ of 'Blue Gem' cabbage seeds age 0 to $28 \mathrm{~d}$ and (B) time to visible germination of cabbage seeds age at $40{ }^{\circ} \mathrm{C}$ and $70 \%$ relative humidity from 0 to $28 \mathrm{~d}$.

Table 1. Comparison of three seed quality indicators performed on 'Blue Gem' cabbage seeds shows that the anaerobic-to-aerobic (ANA) ratio was more sensitive in detecting early-aging events (age 7-14 d) than the other methods tested [germination and coefficient of rate of germination (CRG) index]. The ANA ratio also required significantly less incubation time (24 vs. $120 \mathrm{~h})$. Values within a column followed by the same letter do not differ significantly according to Student's $t$ test groupings $(P=0.05)$.

\begin{tabular}{lccc}
\hline Time aged $(\mathrm{d})$ & ANA ratio & Germination $(\%)$ & CRG index \\
\hline 0 & $15.4 \mathrm{a}$ & $91.5 \mathrm{a}$ & $50.9 \mathrm{a}$ \\
7 & $5.7 \mathrm{~b}$ & $91.5 \mathrm{a}$ & $45.5 \mathrm{ab}$ \\
14 & $1.4 \mathrm{c}$ & $83.0 \mathrm{a}$ & $41.4 \mathrm{~b}$ \\
21 & $0.6 \mathrm{c}$ & $62.0 \mathrm{~b}$ & $28.8 \mathrm{c}$ \\
28 & $0.4 \mathrm{c}$ & $27.0 \mathrm{c}$ & $23.4 \mathrm{~d}$ \\
Test duration $(\mathrm{h})$ & 24 & 120 & 120
\end{tabular}

water per g of dry seeds was sufficient for germination (radicle emergence) given enough time, however, the test samples were processed before radicle emergence. The control intact seeds produced less ethanol than intact aged seeds at each moisture level tested. Intact seeds aged for 14 or $28 \mathrm{~d}$ had increased ethanol production with increasing seed moisture concentration $(>0.54 \mathrm{~g}$ of water per gram of seeds). This result created concern that increased glucose availability from the buffered 

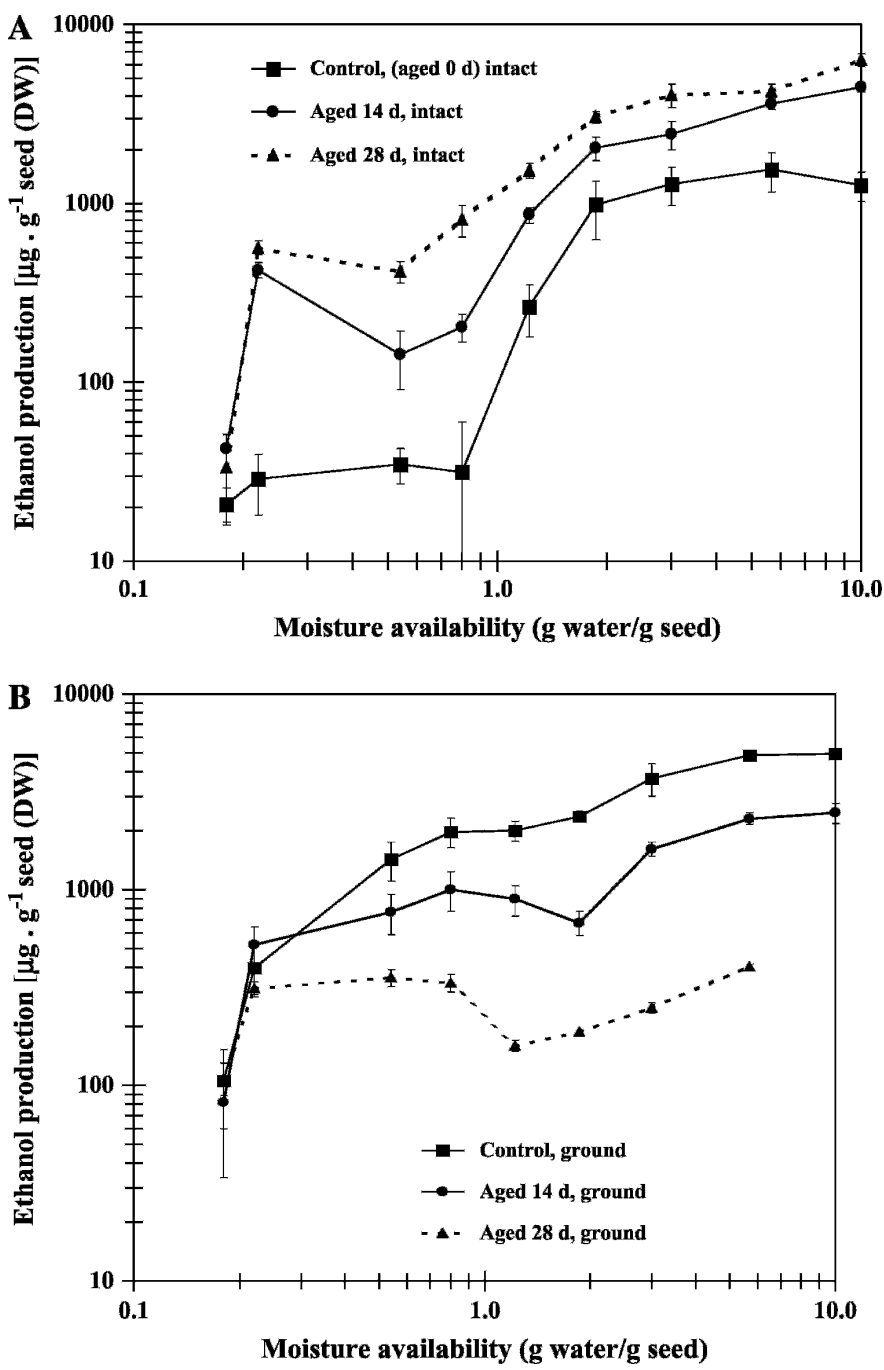

Fig. 2. Ethanol produced (mean $\pm \mathrm{SE}$ ) in response to seed moisture concentrations and varying seed aging in 'Blue Gem' cabbage seeds $(0,7$, or $14 \mathrm{~d}$ at $40{ }^{\circ} \mathrm{C}$ and $70 \%$ relative humidity). (A) Intact seeds and (B) ground seeds. The amount of ethanol produced by 'Blue Gem' cabbage seeds in the anaerobicto-aerobic (ANA) index test was influenced by the amount of moisture available to the seeds and the duration of seed aging treatment. The opposite of intact seeds, ground-seed, ethanol production was higher in control than in aged seeds, with $\geq 0.54 \mathrm{~g}$ of water per gram of seeds.

glucose imbibing solution may have been the substrate for the increased ethanol production. A verification test (Johnson, 1998) demonstrated that increased glucose availability from the buffer during incubation did not explain the increase in ethanol production with increasing moisture concentration in aged intact seeds.

Grinding the seeds altered the ethanol production in relation to seed quality (Fig. 2B). The opposite of intact seeds, groundseed ethanol production, was higher in control than in aged seeds, with $\geq 0.54 \mathrm{~g}$ of water per gram of seeds (Fig. 2B). As in the intact aged seeds, ground seeds (control and aged) demonstrated a general pattern of increasing ethanol production with increasing moisture availability during incubation.

INFLUENCE OF OXYGEN AVAILABILITY ON ETHANOL PRODUCTION. Seeds with $>1.86 \mathrm{~g}$ of water per gram of seeds were submerged under the imbibing buffer solution and would have experienced a lack of sufficient oxygen for germination.
Reduced ethanol production from $<1.86 \mathrm{~g}$ of water per gram of seeds (Fig. 2A) was likely due, in part, to insufficient moisture availability (Vertucci and Leopold, 1984, 1986) and in part to the confounding availability of oxygen. Determination of the point at which hydration level was sufficient and oxygen was inhibitory to ethanol production was the purpose for the nitrogen glove box experiment. Comparison of ethanol production from control intact seeds incubated at ambient $\mathrm{O}_{2}$ with seeds incubated in a nitrogen glove box, low oxygen environment $\left(<1 \% \mathrm{O}_{2}\right)$ is shown (Fig. 3A). This comparison revealed that oxygen was a factor in the ANA ratio when the moisture concentration was $<1.22 \mathrm{~g}$ of water per gram of seeds. That is, sufficient oxygen for respiration resulted in reduced ethanol production when seed moisture was $<1.22 \mathrm{~g}$ of water per gram of seeds. Aged intact seeds demonstrated little difference in ethanol production between seeds incubated in the nitrogen and ambient oxygen environments (Fig. 3B). This lack of difference in ethanol production of intact aged seeds incubated in these two environments suggests that respiration and oxidative phosphorylation are not functional biochemical pathways in
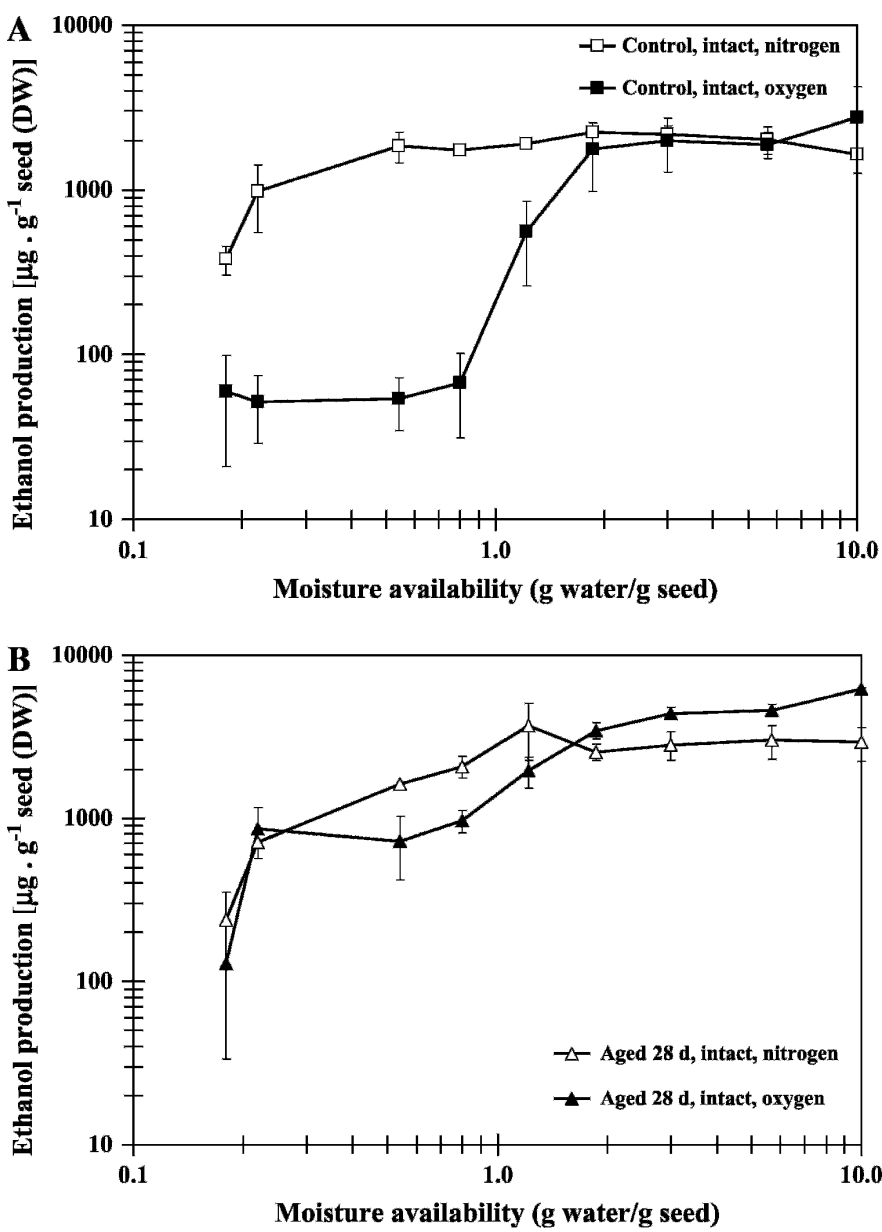

Fig. 3. Ethanol produced (mean $\pm \mathrm{SE}$ ) in 'Blue Gem' cabbage seeds in response to seed moisture concentrations in nitrogen and ambient oxygen environments. (A) Control (nonaged) intact seeds and (B) seeds aged for $28 \mathrm{~d}$ at $40{ }^{\circ} \mathrm{C}$ and $70 \%$ relative humidity. The control (nonaged) intact seeds incubated in an ambient oxygen environment experienced hypoxic conditions when moisture availability reached $1.22 \mathrm{~g}$ of water per gram of seeds. Aged intact seeds demonstrated little difference in ethanol production between seeds incubated in nitrogen and ambient oxygen environments, suggesting that respiration or oxidative phosphorylation were not functional in the intact aged seeds. 
the intact aged seeds. The study cannot predict the point of the lesion (i.e., point of malfunction in the oxidative phosphorylation pathway), however, other work suggests that the loss of cytochrome $\mathrm{C}$ function might be an early seed-aging event (Amable and Obendorf, 1986). Oxygen had little influence on ethanol production from ground nonaged seeds (Fig. 4A). Control ground seeds showed elevated ethanol production in the nitrogen compared with the oxygen environment only if seed moisture was $\leq 0.22$ g of water per gram of seeds. Ethanol production from aged ground seeds was lowest of the four seed treatment conditions (i.e., control intact, control ground, aged intact, aged ground; Fig. 4B). Sufficient oxygen for respiration resulted in reduced ethanol production when seed moisture was $\leq 1.22$ g of water per gram of seeds.

SEed integrity EXPERIMENTS. In aged seeds, there was a general decrease in ethanol production with increasing degree of seed damage in the aerobic and hypoxic conditions (Fig. 5). Aged intact seeds produced the greatest amount of ethanol. A single puncture wound made with a sewing needle was sufficient to reduce ethanol production in aged seeds by $40 \%$ in the aerobic and hypoxic conditions. Grinding aged seeds further reduced ethanol production capacity $(60 \%$ less than intact in the aerobic condition and 95\% less than intact in the
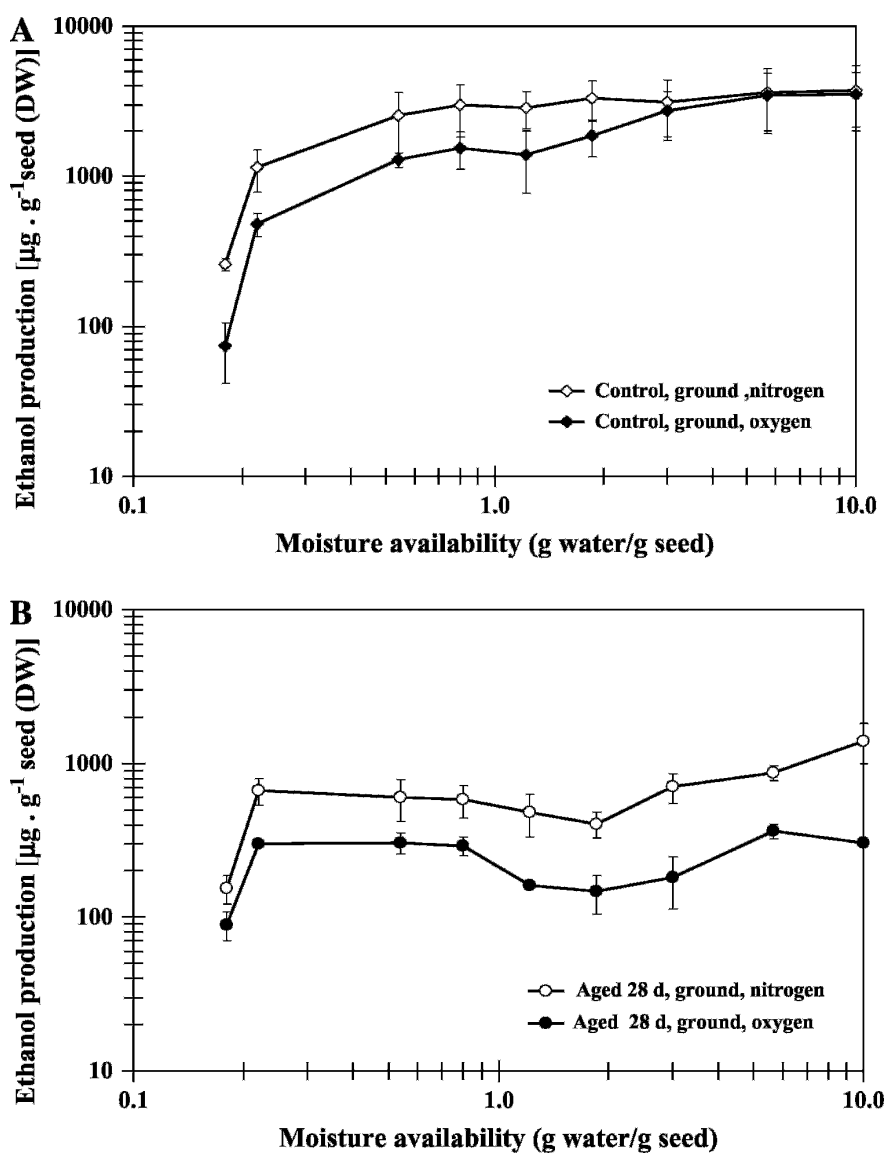

Fig. 4. Grinding the seeds (whether control or aged) yielded similar ethanol production levels in ambient oxygen and nitrogen incubation environments, suggesting that grinding interferes with the respiration or oxidative phosphorylation pathways. Ethanol produced (mean $\pm \mathrm{se}$ ) in 'Blue Gem' cabbage seeds in response to varying seed moisture concentrations in nitrogen and ambient oxygen environments. (A) Control (nonaged) ground seeds and (B) seeds aged for $28 \mathrm{~d}$ at $40{ }^{\circ} \mathrm{C}$ and $70 \%$ relative humidity.

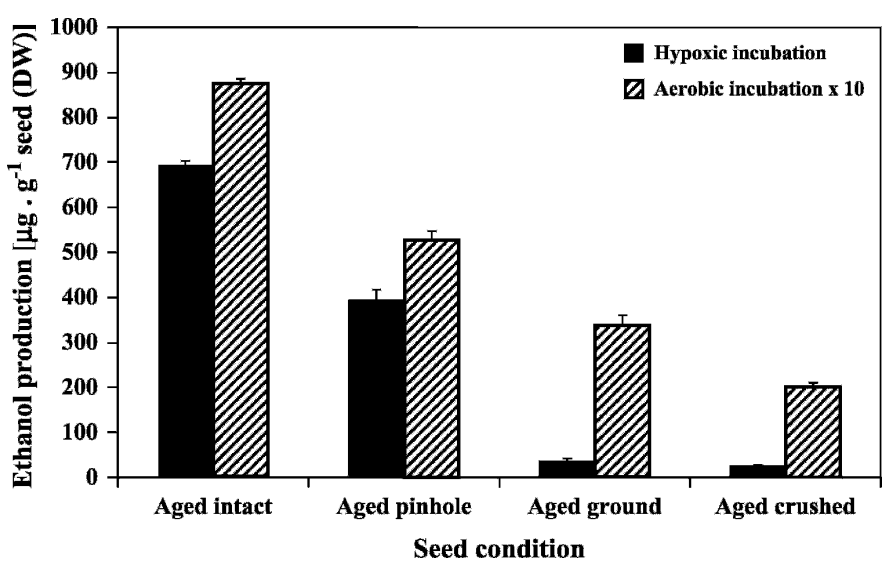

Fig. 5. Aged 'Blue Gem' cabbage seeds were treated four ways, each representing a progressive increase in damage to seedcoat integrity: 1) intact whole seed, 2) pinhole punctured, 3) ground, and 4) crushed seed. Increased seedcoat damage resulted in decreased ethanol production (mean $\pm \mathrm{SE}$ ) in hypoxic and aerobic environments. Aerobic data are multiplied by 10 for scale comparison.

hypoxic condition). The most damaged seed, crushed seed, produced less ethanol than the other treatments $(75 \%$ less than intact in the aerobic condition and $95 \%$ less than intact seeds in the hypoxic condition). From this result and the work of others (Ellis et al., 1990; Horcicka and Hosnedi, 1993; Khan et al., 2005; Leopold and Musgrave, 1980; Leprince et al., 1995; McDonald et al., 1988; Oliveira, 1984; Pretorius and Small, 1992; Tully et al., 1981; Woodstock and Taylorson, 1981; Wolk et al., 1989), we reasoned that upon adding moisture to the seeds, a rapid, uncontrolled hydration may occur in seeds with damaged seedcoats. One function of the seedcoat is to control the rate of hydration in the early stages of seed germination. With the loss of seedcoat integrity, rapid hydration can create extensive damage of cells and cell components (Duke and Kakefuda, 1981; Dunn et al., 1980; Sack et al., 1988; Schoettle and Leopold, 1984; Spaeth, 1987, 1989; Spaeth and Hughes, 1987). The punctured/ground/crushed aged seeds may have been subject to sufficiently rapid hydration and resulting cellular damage as to interfere with cell components and enzyme function. In the case of the ground aged seeds, we would expect that in addition to hydrational-damage of ADH function, the aging treatment also might further add to the decline of ADH function (Amable and Obendorf, 1986). If this were the case, then we would expect that $\mathrm{ADH}$ enzyme function would be impaired in the aged ground seeds compared with aged intact seeds.

Tetrazolium TeST OF DEHYDROGENASE ACTIVITY IN GROUND SEEDS. Tetrazolium staining tests on the ground aged and control seeds and the pinhole damaged aged and control seeds support the possibility that lowered ethanol production is from rapid-hydration damage of $\mathrm{ADH}$ enzyme function in ground aged seeds. Lack of staining indicates a lack of dehydrogenase enzyme function. In pinhole-damaged seeds, determinations of absorbance at $475 \mathrm{~nm}$ showed that pinhole-damaged aged seeds stained $\approx 40 \%$ less than the pinhole-damaged nonaged seeds. When more extensive damage was applied by grinding, the reduction in dehydrogenase activity was even greater. Aged ground seeds stained $\approx 70 \%$ less than the control ground seed. A lack of reduced staining in aged seeds of the pinhole-damaged and ground seeds suggests that general cell death resulting in the loss of $\mathrm{ADH}$ enzyme function through rapid-hydration 
damage may play a role in the reduced ethanol production observed in aged ground seeds.

\section{Conclusions}

The ANA ratio test proved to be a sensitive indicator of cabbage seed quality in tests performed on cabbage and was more sensitive to early deterioration than percentage germination or the CRG index. The ANA ratio test was superior in practice as it could be completed in $24 \mathrm{~h}$, whereas up to $120 \mathrm{~h}$ was required to obtain percentage germination and the $\mathrm{CRG}$ index values. The standard germination test for cabbage requires $10 \mathrm{~d}$ (240 h; AOSA, 1993).

Seed moisture content can influence ethanol production in at least two ways. At low seed moisture concentration (aerobic), water is needed for hydration of cellular components (e.g., membranes and enzymes) required in the metabolic pathway of fermentation. Lack of sufficient water for normal cellular function has the potential to reduce ethanol production. At high seed moisture concentrations, water creates a hypoxic environment that favors ethanol fermentation over aerobic respiration. To select an aerobic seed moisture concentration to optimize the ANA ratio test, differences in ethanol production between control and aged seeds were determined. The optimal moisture availability levels were different for intact and ground seeds.

The use of a nitrogen glove box provided the opportunity to test the influence of seed moisture concentration on ethanol production in the absence of oxygen. Nitrogen, rather than water, was used to create the hypoxic condition. We verified from these data and comparison with ethanol production in ambient oxygen conditions that oxygen and moisture contributed to differential ethanol production in aged and control seeds. After separation of these two factors, it was evident that the influence of water concentration to drive the process of fermentation reached maximum at $0.54 \mathrm{~g}$ of water per gram of seeds or $1.8 \mathrm{~g}$ of water per gram of seeds in the nitrogen environment or the ambient oxygen environment, respectively. The difference between these saturation points is probably from contaminating-pore-space oxygen remaining in the hypoxic environment created by excess water. Pore-space oxygen was probably absent in the hypoxic environment created by nitrogen.

The difference in ethanol production between nonaged highquality intact and nonaged high-quality ground seeds might be explained by rapid hydration damage in the ground seeds during incubation. The increased ethanol production from the nonaged high-quality seeds from grinding suggests that damage has occurred at some point in the respiration pathway, leading to fermentation. A likely site of the damage is mitochondrial integrity, especially dissociation of cytochrome C (Amable, 1985; Amable and Obendorf, 1986). During normal seed maturation drying, cytochrome $\mathrm{C}$ dissociates from the inner mitochondrial membrane and reassociates upon rehydration. After aging, the cytochrome $\mathrm{C}$ reassociation appears not to occur (Amable and Obendorf, 1986).

The difference in ethanol production between aged intact and aged ground seeds might be explained by the interplay of two factors. In the aged intact seed, degradation of the respiration pathway (at cytochrome $\mathrm{C}$ ) from aging leading to fermentation may explain the increased ethanol production. In the aged ground seeds, an interplay between degradation of electron transport processes and degradation of ADH enzyme from aging and hydration damage might explain the decreased ethanol production. Reduced tetrazolium staining in the ground aged seeds indicated that the dehydrogenase enzymes (including $\mathrm{ADH}$ ) were significantly impaired compared with those in ground control seeds. In the ground aged tissues, cellular death may have preceded the ANA test.

\section{Literature Cited}

Amable, R.A. 1985. Preharvest water content fluctuation and soybean seed deterioration. Cornell University, Ithaca, NY, Ph.D. Diss.

Amable, R.A. and R.L. Obendorf. 1986. Soybean seed respiration during simulated preharvest deterioration. J. Expt. Bot. 37(182):1364-1375.

Association of Official Seed Analysts. 1992. Seedling evaluation handbook. Handbook on Seed Testing. Contribution No. 35. Association of Official Seed Analysts, Lincoln, NE.

Association of Official Seed Analysts. 1993. Rules for testing seeds. J. Seed Technol. 16:1-113.

Bewley, J.D. and M. Black. 1994. Seeds: Physiology of development and germination. 2nd ed. Plenum Press, New York.

Duke, S.H. and G. Kakefuda. 1981. The role of the testa in preventing cellular rupture during imbibition of legume seeds. Plant Physiol. 67:449-456.

Dunn, B.L., R.L. Obendorf, and D.J. Paolillo, Jr. 1980. Imbibitional surface damage in isolated hypocotyl-root axes of soybean [Glycine max (L.) Merr cv. Chippewa 64]. Plant Physiol. 65:S-139 (Abstr.).

Ellis, R.H., T.D. Hong, and E.H. Roberts. 1990. Effect of moisture content and method of rehydration on the susceptibility of pea seeds to imbibition damage. Seed Sci. Technol. 18:131-138.

Forney, C.F. and D.G. Brandl. 1992. Control of humidity in small controlled environment chambers using glycerol-water solutions. HortTechnology 2(1):52-54.

Frenkel, C., J.S. Peters, D.M. Tieman, M.E. Tizado, and A.K. Handa. 1998. Pectin methylesterase regulates methanol and ethanol accumulation in ripening tomato (Lycopersicon esculentum) fruit. J. Biol. Chem. 273(8):4293-4295.

Garrett, R.H. and C.M. Grisham. 1995. Biochemistry. Saunders College Publishing, New York.

Horcicka, P. and V. Hosnedi. 1993. Effects of moisture on seed damage of peas and soybeans, p. 975-979. In: D. Come and F. Corbineau (eds.). Proc. Fourth International Workshop on Seeds: Basic and applied aspects of seed biology. Association pour le Formation Professionnelle de l'Interprofession Semences (ASFIS), Angers, France.

Johnson, C.F. 1998. The effect of moisture content on two tests of seed quality: Electrical conductance of individual seeds and ethanol production of seed lots under anaerobic and aerobic conditions. Cornell University, Ithaca, NY, Masters Thesis.

Kataki, P.K. and A.G. Taylor. 1997. Ethanol, a respiratory by product: An indicator of seed quality, p. 421-427. In: R.H. Ellis, M. Black, A.J. Murdock, and T.D. Hong (eds.). Basic and applied aspects of seed biology. Kluwer Academic Publishers, Boston.

Kataki, P.K. and A.G. Taylor. 2001. Time course study of ethanol production by corn and soybean to optimize the use of ANA ethanol index as an accurate seed quality test. J. New Seeds $3(1): 1-17$.

Khan, M.M., M.J. Iqbal, and M. Abbas. 2005. Loss of viability correlates with membrane damage in aged turnip (Brassica rapa) seeds. Seed Sci. Technol. 33(2):517-520.

Koch, J.L., M. Horbowicz, and R.L. Obendorf. 1999. Methanol, pectin and pectinesterase changes during soybean seed maturation. Seed Sci. Res. 9:311-320.

Komba, C.G., B.J. Brunton, and J.G. Hampton. 2006. Accelerated ageing vigour testing of kale (Brassica oleracea $\mathrm{L}$. var acephala DC) seed. Seed Sci. Technol. 34(1):205-208.

Leprince, O., C.W. Vertucci, G.A.F. Hendry, and N.M. Atherton. 1995. The expression of desiccation-induced damage in orthodox 
seeds is a function of oxygen and temperature. Physiol. Plant. 94:233-240.

Leopold, A.C. and M.E. Musgrave. 1980. Respiratory pathways in aged soybean seeds. Physiol. Plant. 49:49-54.

Markovic, O. and R.L. Obendorf. 1998. Soybean seed pectinesterase. Seed Sci. Res. 8:455-461.

McDonald M.B., Jr., C.W. Vertucci, and E.E. Roos. 1988. Seed coat regulation of soybean seed imbibition. Crop Sci. 28:987-992.

Obendorf, R.L., J.L. Koch, R.J. Gorecki, R.A. Amable, and M.T. Aveni. 1990. Methanol accumulation in maturing seeds. J. Expt. Bot. 35(152):365-375.

Oliveira, M.D., S. Matthews, and A.A. Powell. 1984. The role of split seed coats in determining seed vigour in commercial seed lots of soyabean as measured by the electrical conductivity test. Seed Sci. Technol. 12:421-427.

Pretorius, J.C. and J.G.C. Small. 1992. The effect of soaking injury in bean seeds on aspects of the oxidative pentose phosphate pathway in embryonic axes. Seed Sci. Res. 2:33-39.

Sack, F.D., A.C. Leopold, and F.A. Hoekstra. 1988. Structural correlates of imbibitional injury in Typha pollen. Amer. J. Bot. 75:570-578.

Schoettle, A.W. and A.C. Leopold. 1984. Solute leakage from artificially aged soybean seeds after imbibition. Crop Sci. 24:835838.

Spaeth, S.C. 1987. Pressure-driven extrusion of intracellular substances from bean and pea cotyledons during imbibition. Plant Physiol. $85: 217-223$.
Spaeth, S.C. 1989. Extrusion of protoplasm and protein bodies through pores in cell walls of pea, bean, and faba bean cotyledons during imbibition. Crop Sci. 29:452-459.

Spaeth, S.C. and J.S. Hughes. 1987. Cellular rupture and release of protoplasm and protein bodies from bean and pea cotyledons during imbibition. Food Microstructure 6:127-134.

Taylor, A.G., D.F. Grabe, and D.H. Paine. 1997. Moisture content and water activity determination of pelleted and film-coated seeds. Seed Technol. 19(1):24-32.

Taylor, A.G., C.F. Johnson, P.K. Kataki, and R.L. Obendorf. 1999. Ethanol production by hydrated seeds: A high-resolution index of seed quality. Acta Hort. 504:153-160.

Tully, R.E., M.E. Musgrave, and A.C. Leopold. 1981. The seed coat as a control of imbibitional chilling injury. Crop Sci. 21:312-317.

Vertucci, C.W. and A.C. Leopold. 1984. Bound water in soybean seed and its relation to respiration and imbibitional damage. Plant Physiol. 75:114-117.

Vertucci, C.W. and A.C. Leopold. 1986. Physiological activities associated with hydration level in seeds, p. 35-49. In: A.C. Leopold (ed.). Membranes, metabolism, and dry organisms. Comstock Publishers, Cornell University Press, Ithaca, NY.

Wolk, W.D., P.F. Dillon, L.F. Copeland, and D.R. Dilley. 1989. Dynamics of imbibition in Phaseolus vulgaris L. in relation to initial seed moisture content. Plant Physiol. 89:805-810.

Woodstock, L.W. and R.B. Taylorson. 1981. Soaking injury and its reversal with polyethylene glycol in relation to respiratory metabolism in high and low vigor soybean seeds. Plant Physiol. 53:263-268. 